\title{
Transgrow (Clinicult) in the laboratory diagnosis of gonorrhoea
}

\author{
M. KOUSA, O.-V. RENKONEN, U. KIISTALA, AND A. LASSUS \\ From the Department of Dermatology and Venereology, University Central Hospital, Helsinki, and the \\ Department of Bacteriology and Serology, University of Helsinki, Finland
}

The microscopical diagnosis of gonorrhoea from Gram-stained slides may be difficult, especially when specimens from females and asymptomatic male carriers are examined. The selective medium for cultivation described by Thayer and Martin (1964, 1966 ) is very reliable for the primary isolation of $N$. gonorrhoeae, and overgrowth by other microorganisms can usually be prevented by the incorporation of suitable chemotherapeutic agents into the medium. There still remains, however, the problem of the transportation of suspect specimens to a distant laboratory, especially in a large country like Finland, which is sparsely inhabited. In Finland, therefore, a modification of the Stuart's transport medium is used (Gästrin, Kallings, and Marcetic 1968).

The present study was undertaken to compare the value of a commercial modification of Transgrow (Clinicult), described by Martin and Lester (1971), as a culture medium for gonorrhoea, with conventional culture after transportation in Stuart's medium.

\section{Material and methods}

Urethral specimens from 313 unselected male patients suspected of having gonorrhoea were studied. Each specimen was taken by a carbon-impregnated cotton swab and immediately inoculated on Transgrow medium (Clinicult; Smith, Kline and French Laboratories, Ltd.). A specimen was simultaneously placed into Stuart's transport medium and sent to the Department of Bacteriology and Serology, University of Helsinki, for culture on two plates of Thayer-Martin medium, one of which also included trimethoprim. The transported material always reached the laboratory within $24 \mathrm{hrs}$ and was immediately inoculated on both plates.

The Clinicult readings were done after $48 \mathrm{hrs}$ ' incubation at $37^{\circ} \mathrm{C}$. and oxidase-positive cultures were regarded as evidence of growth of $N$. gonorrhoeae without microscopical examination of the oxidase-positive colonies. The identification of $N$. gonorrhoeae from specimens inoculated on the Thayer-Martin media was carried out Received for publication January 18, 1973 by conventional laboratory procedures, which included fermentation tests.

\section{Results}

The results are presented in the Table. $N$. gonorrhoeae was found to grow on both the Clinicult and the Thayer-Martin medium in 114 cases (36.4 per cent.) and was absent on both in 169 cases (54 per cent.). In 28 cases gonococci were found only on the ThayerMartin plates and in two cases only on the Clinicult medium. In the two latter cases direct microscopical examination of the urethral discharge had revealed the presence of typical intracellular diplococci. Thus, the results with the Clinicult medium and the ThayerMartin medium agreed in $\mathbf{9 0 . 4}$ per cent. of cases.

TABLE Results of culturing 313 specimens from the urethra of male patients with suspected gonococcal infection

\begin{tabular}{|c|c|c|c|}
\hline \multirow{2}{*}{ Medium } & \multirow{2}{*}{ Result } & \multicolumn{2}{|c|}{ Specimens } \\
\hline & & No. & Per cent. \\
\hline Clinicult & + & & 36.4 \\
\hline Thayer-Martin & + & 107 & 307 \\
\hline Clinicult & + & 2 & 0.64 \\
\hline Thayer-Martin & - & & \\
\hline Clinicult & - & 28 & 8.95 \\
\hline Thayer-Martin & + & & \\
\hline Clinicult & - & 160 & 5 \\
\hline Thayer-Martin & - & 107 & 870 \\
\hline
\end{tabular}

In considering the 144 cases in which a positive result was obtained on either medium or both, the results with the two media agreed in 79.2 per cent. of cases, the Thayer-Martin culture alone was positive in 19.4 per cent. and the Clinicult alone in 1.4 per cent. 


\section{Comment}

In the present study the sensitivity of the Clinicult medium did not reach the level of the ThayerMartin media. The circumstances for the latter were, however, favourable, with a very short transportation time in all cases. It is probable that, with a longer transportation time in Stuart's medium, the sensitivity of the two media would have been more similar. Our results do not confirm those of Martin and Lester (1971), who found a very close agreement between their initial Transgrow medium and the Thayer-Martin medium. The reasons for this may be technical; e.g., in their study, a flat bottle was used instead of the commercial test-tube and a smaller culture area was used in the present study. The Clinicult medium may be too selective or the culture area too small to pick up smaller inocula of gonococcal strains in some cases.

It is suggested that further trials should be performed to settle the role of Clinicult in the laboratory diagnosis of gonorrhoea. For instance, specimens from different sites of the genital tract of asymptomatic female carriers should be studied. The viability of the strains on the Clinicult medium should also be tested, because availability for sensitivity testing is important and gonococcal strains often die on the third day if not further cultivated.

\section{Summary}

A commercial modification of Transgrow medium (Clinicult) was compared with Thayer-Martin medium as a culture medium for gonococci. Urethral specimens from 313 men suspected of having gonorrhoea were tested. The results with the two culture media agreed in $\mathbf{9 0 . 4}$ per cent. of cases, the Clinicult medium gave a false negative result in 9 per cent. and the Thayer-Martin a false negative in less than 1 per cent. The reasons for the lower sensitivity of the Clinicult medium are discussed.

\section{References}

Gästrin, B., Kalings, L. O. and Marcetic, A. (1968) Acta path. microbiol. scand., 74, 371

MARTIN, J. E., JR., and Lester, A. (1971) HSMHA Hlth Rep., 86, 30

Thayer, J. D., and Martin, J. E., JR. (1964) Publ. Hlth Rep. (Wash.), 79, 49

,-- (1966) Ibid., 81, 559

Le Clinicult, milieu de transport et de culture, dans le diagnostic de laboratoire de la gonococcie

SOMMAIRE

Une modification commerciale (le Clinicult) du milieu deo transport et de culture (Transgrow) fut comparé aue milieu de Thayer-Martin comme milieu de culture pouko le gonocoque. Dans 90,4 pour cent des cas, il y eut accord entre les résultats des deux milieux. Le milieu Clinicult donna un résultat faussement négatif dans 9 pour cent des cas et le Thayer-Martin un résultat faussement négatif dans moins de 1 pour cent. On discute les raisons de la moins bonne sensibilité du milieu Clinicult. 